\title{
Bicentenarios, pueblo y representatividad
}

\begin{abstract}
Héctor Grenni ${ }^{1}$
El autor describe las revueltas hispanoamericanas desde la perspectiva del movimiento del 5 de noviembre de 1811 en San Salvador. Partiendo de fuentes primarias, se analizan la participación de los criollos en esas revueltas, la representatividad de quienes las lideraron y la participación popular.
\end{abstract}

The author describes the Hispanic American uprisings from the perspective of the movement on November 5th of 1811 in San Salvador. Based on primary sources, the author analyzes the participation of the Creoles in the revolts, the representativeness of the leaders, and the people's involvement

En estos tiempos de bicentenarios, es pertinente preguntarse acerca de la representatividad de quienes condujeron las revueltas que llevaron, finalmente, a las independencias de las antiguas colonias españolas en América. Presentaremos aquí, en una rápida síntesis, un panorama de las revueltas de las colonias españolas en América a principios del siglo XIX. Se buscará indagar acerca de la representatividad que ostentaban los líderes de esas revueltas.

Las fuentes de la información que usaremos en este trabajo son, fundamentalmente, las 'fuentes directas': las actas de los cabildos de las ciudades donde se declararon revueltas que condujeron a las independencias; la Constitución de Venezuela de 1811; la Carta de Jamaica de Simón Bolívar, y, para el caso de la revuelta de 1811 en San Salvador, los Procesos por infidencia contra los próceres salvadoreños de la independencia de Centroamérica desde 1811 hasta 1818, de Miguel Ángel García. Otros escritos completan las fuentes de información, como el clásico trabajo de A. Dagoberto Marroquín, Apreciación sociológica de la independencia salvadoreña; el de Francisco Peccorini Letona, La Voluntad del Pueblo en la Emancipación de El Salvador; y un escrito de Sajid Herrera, El vocablo "Pueblo" en una época de crisis y de levantamientos populares, publicado en el periódico digital Contrapunto, han aportado mucho a este respecto.

\section{Antecedentes}

Ya en los trescientos años de la colonia habían sucedido numerosas revueltas, algunas ya desde el temprano siglo $\mathrm{XVI}^{2}$. Muchas de ellas representaron un serio

1. Director de la Biblioteca Rafael Meza Ayau, de la Universidad Don Bosco.

2. Cfr. José Andrés-Gallego, Quince revoluciones y algunas cosas más, ed. Mapfre, en versión electrónica, Madrid, 1992. 
cuestionamiento al sistema colonial y tenían fuertes connotaciones sociales o culturales, como la gran rebelión de Túpac Amaru en el Alto Perú en la segunda mitad del siglo XVIII. Ya por entonces las colonias españolas habían comenzado a despertar de su larga siesta colonial y habían visto nacer, a veces súbitamente, movimientos sociales que reclamaban mayores libertades y que sacudieron hasta los cimientos la rígida estructura colonial. Estos reclamos estaban impregnados de una fuerte carga cultural, lo que dotaba al movimiento de implicaciones emotivas de arraigos ancestrales.

Estas revoluciones, sin duda, prepararon el terreno para los movimientos del siglo XIX y, en algunos casos, fueron su caldo de cultivo. Sin embargo, hay diferencias profundas entre éstas y las revueltas de principios del siglo XIX que presentaremos aquí.

No se comprenden las revueltas que condujeron a las independencias en el siglo XIX, sin esas revoluciones del siglo XVIII que las precedieron: América había despertado ya en el siglo XVIII. España no supo darse cuenta e intentó reprimir las revoluciones por la fuerza antes que atender a sus reclamos o intentar un diálogo que podría ir al encuentro de los problemas que las revoluciones planteaban. Logró reprimirlas, pero al costo de acentuar el distanciamiento de los criollos y de un severo desgaste de todo el sistema y de los funcionarios a cargo, desgaste que dejará profunda huella en el sistema colonial español y que será determinante en las primeras de' cadas del siglo XIX.

Probablemente, muchas de las 'revoluciones' del siglo XVIII tuvieron una mayor radicalidad que las 'revueltas' del siglo XIX y que terminaron en las independencias. Los reclamos de aquéllas tenían como fundamento la atención a necesidades que el sistema no lograba atender y que iban contra la esencia misma de la existencia humana: la pobreza, la cultura, las relaciones de trabajo, el acceso a los espacios de decisión. Los reclamos de éstas tenían como fundamento la ampliación de los privilegios de clase o la búsqueda de mayores libertades de una clase que ya los ostentaba; a la postre, la independencia política.

En estas últimas revueltas, las recurrentes alusiones al concepto de 'patria' que se pueden leer en las actas de los cabildos que las reseñan, hacían alusión, fundamentalmente, a la 'patria' de un sector generalmente pequeño de la población: los españoles americanos, que usaban estos conceptos como una forma de definir sus intereses y distinguirlos así de los de los españoles peninsulares. La 'patria' de las revueltas era la patria como era concebida por los criollos. Las mayorías permancieron ajenas a ello. Por lo menos, no hay elementos para fundamentar su participación.

La metrópolis, no supo interpretar estos últimos reclamos y trató de reprimirlos por la fuerza, como sucedió con los del siglo XVIII. Con ello, puso en evidencia que probablemente nunca había logrado comprender el mundo que hacía trescientos años trataba de organizar. La España que llegó a América en el 
siglo XV-XVI era medieval, católica, reconquistadora y semifeudal; siguió siéndolo durantes los tres siglos siguientes. Y tuvo que dialogar con un mundo nuevo, joven, vital, que alimentaba un profundos respeto por el contexto que los rodeaba. Este diálogo fue, frecuentemente, infructuoso y poco a poco se tradujo en cuestionamientos. Y, cuando esos cuestionamientos se transformaron en revueltas y tuvieron como protagonistas a una clase estrechamente ligada al poder político y económico y que deambulaba por los espacios de poder, no pudo controlarlas y se vio superada por ellas.

\section{El 'pueblo': la plebe, los vecinos, el común.}

Se torna necesario, en este contexto, indagar en la representatividad de quienes dirigieron las revueltas del siglo XIX. Los líderes que las dirigieron tenían un cierto grado de representatividad, y con frecuencia, como 'americanos', supieron interpretar el sentimiento de las mayorías cercanas a su estamento social. Ellos no participaban de la marginación en que el sistema colonial dejaba sumidas a las grandes mayorías; por el contrario, participaban de los privilegios. $Y$ cuando ellos quisieron ampliarlos, cuestionaron el sistema desde esos mismos privilegios. $Y$ los cuestionamientos terminaron, a la postre, en escasas dos décadas y media, en las independencias que llevaron al derrumbmiento del todo el imperio colonial. Nos referimos a los españoles americanos, los criollos que dirigieron las revueltas

Es necesario, para ello, detenernos en el alcance de los diversos significados que adquieren, en este contexto, palabras como 'pueblo', 'vecinos', plebe', 'vecindario'... para indicar a la población que participaba en las revueltas en mayor o menor medida, y a quienes representaban quienes declararon las independencias. Conviene preguntarse si aquí estaban representadas también las mayorías generalmente marginadas y hundidas en la pobreza.

Precisamente, la 'relación histórica' citada en los 'Procesos por infidencia...' que mencionamos habla de la 'plebe', refiriéndose a los participantes de las manifestaciones del 5 de noviembre de 1811 en San Salvador, en alusiones cargadas de desprecio. Muchas veces estas alusiones se encontrarán en boca de los criollos, reproducidas en los documentos, que dejaban ver el orgullo de clase, originado en siglos de privilegios coloniales, que acompañaba a la creciente toma de conciencia en las últimas décadas del siglo XVIII y, sobre todo, en las primeras del siglo XIX.

Para ahondar en esto, sigamos aquí las apreciaciones de Severo Martínez Peláez en su ensayo La patria del criollo. Ensayo de interpretación de la realidad colonial guatemalteca, de donde tomamos estas ideas, trabajo que cita Herrera:

“El termino 'plebe', señala el autor, no hacía referencia al color de la piel ni a la ocupación de las personas, sino exclusivamente a su nivel de pobreza y a cierta conducta general que aparecía como propia de la gente pobre de la ciudad. Así, pues, la plebe estaba constituida por 
mestizos, mulatos, zambos negros libres y la multitud de combinaciones que se englobaban en la designacion de 'pardos'; pero habrá pardos acomodados -artesanos, tenderos, artistas- que a nadie se le hubiera ocurrido decir que pertenecían a la plebe. Eran pardos de otro nivel económico y social. Así, también, había artesanos, tenderos y artistas arruinados, no acomodados que pertenecían a la plebe con el tropel de aprendices, oficiales, sirvientes y peones ... "3

Sin duda, el alcance de los términos, que nos serviría para determinar acerca de la representattividad de quienes lideraron las revueltas, y por lo tanto, acerca de la validez de los reclamos, está en buena parte, condicionado por la riqueza. Precisamente, en una sociedad rígidamente compartimentada como la de las colonias españolas, en donde el nacimiento condicionaba en gran medida el lugar social, se tornaba sumamente necesario determinar la ascendencia y el lugar de proveniencia en la definición de los status sociales.

Todo ello condicionaba el lugar que ocuparía la persona en la iglesia cuando se cantaba el Te Deum, el orden en el cual saludaría a las nuevas autoridades, la pompa con que celebraría -y debía costear!- los acontecimientos familiares, la ostentación y el lujo que debía hacer evidente, las posibilidades de acceder a los empleos públicos y de beneficiarse de ellos, la posibilidad de beneficiarse en los grandes negocios...

Cuando se consultan las fuentes y los documentos queda enseguida en evidencia la multiplicidad de significados de la palabra 'pueblo' en sus múltiples acepciones. En los documentos salta a la luz la ambigüedad del concepto, especialmente en una sociedad sumamente jerarquizada. Quienes las escibieron les dieron significados de alcances variados, aunque generalmente hacían alusión a grupos estrechos, los grupos de quienes quienes estaban en condiciones de participar en las revueltas y que tenían intereses que podrían ser de peso en ellas. A este propósito, precisamente, se pregunta M. A. García en su lúcido trabajo sobre la consideración sobre el indio en el ambiente peruano:

“...al hablar del pueblo ¿a qué nos referimos? ¿A la comunidad en su conjunto? ¿A la estructura interna de la sociedad? El término es tan ambiguo que podríamos referirlo tanto a la ciudadanía como a una nación indefinida y por hacer. Lo cierto es que la independencia conllevó como meta ideal crear repúblicas de ciudadanos que congregasen al conjunto social por completo y, sin embargo, su posterior evolución demostró todo lo contrario, sobre todo y significativamente en aquellos países donde el componente indígena era mayoritario." 4

3. Martínez Peláez, S., La patria del criollo. Ensayo de interpretación de la realidad colonial guatemalteca, México: Ediciones en Marcha, 1994, pp. 287-300, citado por Herrera, S., en revista Contrapunto, en versión electrónica, en http://bicentenario.contrapunto.com.sv/index.php?option=com_content\&view=article\&tid=6\&l temid $=3$

4. García, M. A, De peruanos e indios: La figura del indígena en la intelectualidad y políticas criollas (Perú: siglos XVIII-XIX), ed. Universidad Internacional de Andalucía, Huelva, 2007, pág. 8. 
Los 'vecinos', el 'pueblo', el 'común', ‘la parte más sana y principal', los 'ciudadanos' se dirá en las constituciones de los países que llegaron a la independencia ... Todos estos conceptos generalmente se resumían en los intereses de la clase de los criollos, que desde su propia visión de la realidad y de la 'patria', supieron apropiarse de los movimientos que terminaron en las independencias, darles interpretaciones delimitadas por sus intereses y condicionar así el desarrollo de las revueltas y las posteriores independencias. Al fin de cuentas, fueron ellos quienes declararon las independencias y quienes escribieron las constituciones.

Las relaciones entre los líderes de esos movimientos y las mayorías es de difícil rastreo y ofrece muy variadas propuestas: desde los populismos, como los casos de Juan Manuel de Rosas y sus 'gauchos' en las Provincias Unidas del Río de la Plata, o José Antonio Páez y sus 'llaneros', en Venezuela, hasta los casos de rígida disciplina miltar de los generales José de San Martín o Antonio Sucre, ya cuando había que consolidar las independencias a fuerza de fusiles; desde la respetuosa actitud ante la soberanía popular de líderes y partidarios de una amplia participación de las mayorías en la definición de las naciones emergentes, como José Gervasio Artigas en la Banda Oriental, hasta las propuestas de 'civilización o barbarie' de Domingo Faustino Sarmiento en Argentina, o los liderazgos iluminados de quienes habían pasado por las universidades coloniales o de comerciantes conscientes de sus intereses o funcionarios y allegados a las esferas del nuevo poder político emergente... El concepto de pertenencia a una comunidad nacional o patria, y con ello, el de ciudadanía, ha tenido en esos tiempos múltiples interpretaciones.

La conciencia de formar parte de una comunidad que puede exteriorizar sus necesidades y su forma de pensar y concebir las relaciones sociales se puso en evidencia en los movimientos revoltosos de principios del siglo XIX en las colonias españolas. Esta idea fue, con frecuencia, unida a la de la soberanía popular, en la cual reside el poder político y ante la cual deben rendir cuentas los depositarios del mismo. Sí,

"La idea de ser 'parte integrante de la Soberanía', sin distinción alguna del lugar en donde se hubiese nacido, era aquel derecho de igualdad reconocido por el decreto de 22 de enero de 1809, emitido por la Junta Suprema Central de España y las Indias, que se estaba poniendo a prueba en la Intendencia san salvadoreña"5

era una idea a la que podía recurrirse para justificar los hechos de los movimientos que cuestionaban el sistema colonial, y más aún si ésta idea estaba fundamentada en un decreto de la Junta Central que en España había tomado el poder político en sus manos en lugar del monarca cautivo, era éste un

5. Herrera, S., El vocablo 'Pueblo' en una época de crisis y levantamientos populares: San Salvador, 1811 (1), en revista electrónica Contrapunto, 9 de agosto de 2010, tomado de http://bicentenario.contrapunto.com.sv/ index.php?option=com_content\&view=article\&id=6\&ltemid $=3$ 
argumento que podía justificar la deposición de las autoridades y la existencia misma del movimiento.

El mismo proceso de revisión del concepto de soberanía en que se hallaban envueltas las clases 'ilustradas' de España en las primeras décadas del siglo, se había trasladado a América, y se puso en evidencia en los cuestionamientos al sistema colonial, en los liderazgos de las revueltas y en las 'patrias' resultantes de los procesos de independencia. Este intento de que el poder 'vuelva al pueblo' se encontrará varias veces en los argumentos revolucionarios. A ello recurrirán con frecuencia los líderes de las revueltas.

La soberanía ahora, después de las 'nuevas ideas', radicaba en 'el pueblo', a quien volvía el poder político cuando éste era cuestionado. La prisión del monarca español provocaba un momento propicio para el cuestionamiento y para encarar estas cuestiones. El problema consistía, entonces, en determinar quiénes podían 'hablar en nombre del pueblo', o quiénes podían representarlo. La alusión a las mayorías en este aspecto es ineludible. $Y$ en una sociedad eminentemente urbana como la sociedad colonial, donde los espacios de poder político y de decisión económica se dirimían en las ciudades, aún existiendo una inmensa cantidad de habitantes en las zonas rurales, la alusión a las mayorías se tornaba sumamente compleja y de difícil consenso.

En los tiempos de las revueltas esta alusión dejó de lado los amplios sectores de población radicados en las zonas rurales y en los poblados alejados de las capitales. Era en esas capitales, precisamente, que se definían los espacios de poder político y en ellas, a la postre, en donde se llevaron a cabo las revueltas. Los sectores rurales y las ciudades alejadas del centralismo colonial vieron las revueltas desde lejos, aunque muchas veces reaccionaron ante ellas, para adherir o para resistirse a los cambios.

La participación de las ciudades del entorno no siempre fue de adhesión, y con frecuencia fue de indiferencia e incluso de oposición. Contribuían a ello viejos antagonismos, recelos, disputas, asfixias burocráticas y deseos de mayores autonomías. Esto revelaba la actitud de las minorías dirigentes de regiones apartadas de los centros de poder ante movimientos generados por la lucha por espacios a los cuales no aspiraban: bastaba la conservación de sus espacios locales: los intereses de estas minorías estaban más bien centrados en la conservación de sus haciendas y beneficios locales. Cuando adhirieron a las revueltas, añadieron a éstas nuevos intereses que había que tener en cuenta a la hora de decidir el rumbo del movimiento.

Esta situación quedó en evidencia en numerosas ocasiones: en la revuelta de 1810 de Buenos Aires, las provincias se opusieron al movimiento que depuos a las autoridades coloniales; en 1811 en San Salvador, las ciudades del interior de la Intendencia se opusieron al movimiento de 1811. 
Es difícil saber si las independencias fueron la manifestación del deseo de las mayorías, o, más bien, la manifestación de intereses de clase. El Dr. Sarbelio Navarrete, para el caso de la Capitanía General de Guatemala, Reyno de Guatemala desde el siglo XVIII, dice que

"La independencia era un hecho inminente: estaba en el aire que se respiraba. Una declaratoria solemne de la capital tenía que resonar fuertemente en las provincias y producir la liberación de toda Centroamérica". ${ }^{6}$

Algunos testimonios de testigos en el juicio seguido contra Manuel José Arce en los años 1814 a 1816 mencionan que la independencia era el objetivo de los movimientos revoltosos, como el testimonio de Casimiro Antonio Morales:

“...Casimiro Anto. Morales en qe. dice de la independencia qe. se trataba ... qe. es pubco. y notorio y generalmente ha Oido decir qe. atratar de independencia ... ¿si sabe el Objeto aque se dirigieron los pasos revolucionarios ...? Respondio qe. al de la independencia o como se explicaban los mismos Facciosos al Sacudir el yugo del Gobno. Monarquico según es pubco. Y notorio en esta ciudad". ${ }^{7}$

No obstante, estos testimonios no ofrecen grandes garantías de credibilidad, tanto por su escaso número como por los acontecimientos posteriores. Cuando los revoltosos tomaron el poder en 1811 en San Salvador no declararon la independencia y, por el contrario, juraron fidelidad a Fernando VII.

\section{Las revueltas hispanoamericanas}

La revuelta de Buenos Aires de mayo de 1810, que tomaremos como ejemplo, había sido protagonizada por los criollos porteños, 'la parte más sana y principal del vecindario' de la ciudad. Este término lo encontraremos reptido varias veces en los documentos de esos años. En esta acta se indica que la idea que mantenía el movimiento dentro del círculo de influencia de los criollos debe mantenerse: las ciudades 'del interior' deben elegir representantes criollos (de 'la parte más sana y principal', aquí también) y mandarlos a que se integren a la Junta que ya había sido creada y que ya había comenzado a funcionar. De este modo, los criollos porteños se adueñaban del concepto de soberanía popular en representación de un pueblo que, probablemente, ni siquiera se había enterado de los hechos y que, sin duda, no había sido consultado antes.

Sin duda, este análisis bien puede aplicarse a la mayoría de los movimientos revoltosos de principios del siglo y que, a la postre y después de muchas vicisitudes, terminaron por declarar la independencia. Pensamos que esto bien puede aplicarse a la revuelta de San Salvador de 1811, donde, luego de una

6. Sarbelio Navarrete, citado por Peccorini Letona, Francisco, La Voluntad del Pueblo en la Emancipación de El Salvador, Dirección de Publicaciones e Impresos, San Salvador, 1972, pág. 67.

7. Declaración de Casimiro Morales en su lecho de muerte el 6 de mayo de 1816, en el juicio por infidencia contra Manuel José Arce, en García., M. A., Procesos por infidencia..., pág. 58-59, en Anexo 20, pág. 19. 
primera manifestación de efervescencia protagonizada por los habitantes de los suburbios de San Salvador, los criollos -'las personas condecoradas', diría la 'relación histórica-, se apropiaron del movimiento.

Las ciudades del interior de la Intendencia reaccionaron con indiferencia o con hostilidad, recurriendo también aquí a la fidelidad a la monarquía para justificar su postura, y con ello, a las autoridades coloniales cuestionadas: los intereses locales, incluso en una región tan pequeña como la Intendencia de San Salvador, prevalecieron por sobre la propuesta de la capital.

Con todo, algunas revueltas se apartan de este análisis. Podemos mencionar el movimiento de los sectores rurales del sur del Virreinato de Nueva España, que culminó en el Congreso de Anáhuac, que declaró la independencia y propuso incluso algunas reivindicaciones de carácter social que tendían a la igualdad. Pero se trata aquí de una revuelta que no había sido originada en la capital del Virreinato y que, seguramente, tenía muchos reclamos que hacerle. Se puede añadir aquí también el movimiento de la Banda Oriental del Río dela Plata liderado por José Gervasio Artigas, especialmente en los momentos del éxodo del pueblo oriental ${ }^{8}$. Ambos movimientos, sin embargo, tuvieron características especiales que no permiten incluirlos en la generalidad de los que estamos tratando. En ambos casos se trata de movimientos iniciados lejos de la capital de la entidad administrativa colonial y bajo el liderazgo de una figura conocida y de gran ascendencia sobre las mayorías.

\section{Liderazgos, representatividades y localismos}

Quienes lideraron las revueltas hispanoamericanas fueron los criollos, esa clase constituida por españoles nacidos en América, que aspiraban a ampliar sus privilegios económicos y políticos reclamando mayores libertades, y que, con frecuencia, hicieron de ellas las banderas en nombre de las cuales se realizaron las revueltas. Tenían una cierta ascendencia sobre quienes conformaban las demás clases sociales y ejercieron distintos tipos de liderazgos.

En este aspecto, merece destacarse la actitud de José Gervasio Artigas: nombrado por aclamación Jefe de los Orientales en el sitio de Montevideo en 1812, en el momento de nombrar a los representantes 'orientales' a la Asamblea de 1813 en Buenos Aires, dijo frente al pueblo que lo seguía: 'Mi autoridad emana de vosotros y ella cesa ante vuestra presencia soberana', en una clara alusión a los depositarios de la soberanía. No se trata aquí de una revuelta que, como en los casos anteriores, tuvo lugar en un momento determinado: la revuelta del

8. "El éxodo oriental o éxodo del pueblo oriental fue la emigración colectiva de habitantes de la Banda Oriental que siguió a José Artigas hasta el Salto Chico (actual ciudad argentina de Concordia) después del armisticio de octubre de 1811. Los protagonistas lo denominaron "la redota"... El éxodo es considerado uno de los hechos centrales y primogénitos en la formación del sentimiento nacionalista uruguayo, una especie de conciencia prefigurada de ser un pueblo "distinto" o "diferente" al porteño, al español y a cualquier otro, por eso se le considera al hecho de la Redota, como fermental para el nacimiento de la 'orientalidad'”. Tomado de http:// www.uruguayeduca.edu.uy/Portal.Base/Web/verContenido.aspx?ID=209782 
pueblo oriental tuvo lugar a lo largo de varios años y tuvo expresiones diversas. Pero aquí se quiere poner en relieve la concepción de representatividad. Fuera de esta referencia, no se encuentran posturas de este tipo en las revueltas hispanoamericanas.

Las revueltas americanas coloniales se llevaron a cabo bajo la iniciativa de una clase social privilegiada, los criollos. Éstos alcanzaron a captar los descontentos populares hacia el sistema y los hicieron propios. Es en esos tiempos que comienza el uso frecuente en los documentos emanados desde los movimientos, de la palabra 'patria', para significar la 'tierra americana', en oposición a la 'tierra española' y poara diferenciarla de la colonia.

Los documentos que narran las revueltas usarán los términos de la colonia para referirse a la población, de distintos modos: 'los vecinos', 'el común', 'la parte más sana y principal’, ‘el pueblo’, ‘el vecindario’... En algunos círculos criollos 'ilustrados' usaron con frecuencia el término 'americanos', no exento de una fuerte dosis de orgullo y de una cierta carga emotiva de difícil precisión, y que hacía alusión a la conciencia de haber nacido en tierras de la colonia y no en España. Ello planteaba, al mismo tiempo, una fuerte oposición a lo peninsular. Esto ponía en evidencia el viejo resquemor criollo para con los españoles peninsulares y rescataba antiguas pretensiones.

Todos estos conceptos, sumamente confusos en un primer momento, especialmente en los tiempos de las primeras revueltas de la primera mitad de la segunda década del siglo XIX, podrán justificar después tanto los movimientos que culminaron con las independencias políticas como los que culminaron con el desmembramiento en varios estados de las unidades politicas regionales de los tiempos de la colonia: Virreinatos, Capitanías Generales, Intendencias. Veamos qué dice al respecto Andrés-Gallego:

“El recurso a la palabra 'americano' como un recurso nacional es tardío, cultista y raro en el siglo XVIII. No lo hemos encontrado ni una sola vez en la documentación de 1762-1767 ...aparece en algún texto de 1780-1781 relativo a la sublevación de Túpac Amaru (Túpac Amaru, americano rey, reza un verso de entonces) y está asimismo implícito - a escala menor en 'peruano'- en varios de los documentos públicos del propio caudillo inca, por citar algunos ejemplos; así, cuando contrapone 'gente peruana' a 'gente europea', y considera en la primera, expresa e intencionalmente, tanto a los criollos como a los 'naturales, por ser todos paisanos y compatriotas'.'

José Gervasio Artigas usará el término 'genio americano' y 'americanos' para diferenciarse de los indios, a quienes llamará 'indianos'; Francisco de Miranda escribirá la 'Proclama a los americanos' en 1801 y en España la 'Carta a los americanos', del poeta juntista Manuel José Quintana en las Cortes de Cádiz, 
buscará despertar el sentimiento de pertenencia entre los americanos que tomaron el poder político en América, y a quienes se intentaba sumar a las juntas españolas que surgieron en España desde 1808 en adelante.

Los conceptos ‘americano’, ‘patria', ‘nación’ fueron evolucionando rápidamente en la efervescente América colonial del siglo XIX. Como dice Andrés-Gallego,

“En realidad las mismas palabras nación y patria y sus derivados tenían otro sentido dominante en 1762-1767, distinto del que hoy solemos darle y adquirieron muy pronto, aún en el siglo XVIII pero sobre todo en el siglo XIX. Hasta entonces solían circunscribirse, curiosamente, al ámbito de lo que podía ser la antigua gen, esto es, al gentilicio o al de la estricta jurisdicción territorial, normalmente local y algunas veces provincial." 10

El predominio de la acepción localista del término fue indicativo de la preeminencia de los intereses locales por sobre los de la jurisdicción colonial en que estaban insertos sus habitantes. En el Reyno de Guatemala, la independencia puso en luz la capacidad de los intereses locales para sobreponerse a los intentos de unificación, intereses que, a la postre, lograron imponerse: si bien se dejaron de lado en el momento de las declaración de la independencia, en el momento de definir el modelo de país estos mismos intereses rechazaron toda pretensión centralista. Esto, a la par que ponía en evidencia la escasa integración de las jurisdicciones coloniales españolas, provocó el surgimiento de naciones independientes que no respondían plenamente a ellas.

En estos términos,

"el mismo predominio de la acepción puramente local nos encontramos en América: en Santiago del Estero, cuyos capitulares, a la hora de atribuir los oficios añales de la ciudad, se comprometían a buscar 'personas beneméritas, timoratos (sic) y que desempeñasen el serv(icio) o de ambas Magestades (sic) y mirasen por el bien común general de la Patria, sus vesinos (sic) y moradores..."11.

Y continúa Andrés-Gallego:

"En el otoño de 1766, cuando los de la Audiencia de Guatemala se adelantaron a ofrecer rebajas y mejoras a la gente en vista de la amenaza de tumulto, publicaron edictos donde decían decidirlo como 'Padres de la Patria'. Y ya hemos dicho que los del ayuntamiento de la ciudad se ofrecían a respaldar el arrendamiento del estanco del aguardiente con sus propios caudales 'por el bien de la Patria'. "Sólo tiempo después la palabra llega a abarcar todo el continente: "América es nuestra Patria (...)" 12 


\section{Patrias, patriotismos y revueltas}

Y en adelante, los movimientos americanos usarán la palabra 'patria' en sus documentos, donde aparecerá unida al concepto de 'pueblo', 'nación, o 'estado', indistintamente. Y los criollos, que se harán dueños del descontento y de las revueltas, se harán dueños también de estos conceptos y usarán estas palabras definir sus intereses. No son los mestizos, ni los indios ni los negros quienes usarán esas palabras, sino los criollos.

Y de 'patria' se pasará a 'patricio', 'compatriota', 'paisano', 'patriota', 'patriótico... y encontraremos estas palabras repetidas veces en las actas de los cabildos y en las declaraciones de independencia. Y el término se reducirá -o se ampliará- hasta las dimensiones de los intereses de quienes lo empleaban para expresar su propio concepto de bien común, de nación y en general, de las cosas de que incumbían a todos y daban sentido al movimiento. Si en España el concepto contribuyó a unir a la nación en defensa de los intereses nacionales contra la invasión napoleónica, en América el término adquirió un carácter netamente localista.

Algo de eso hay en Bolívar ya desde 1812, cuando se dirige a los habitantes de Venezuela como 'conciudadanos', a quienes pide aceptar sus consejos dirigidos con 'patriótico celo' en el Manifiesto de Cartagena. Bolívar llama a su Manifiesto, 'Memorias'.

"Dignaos, oh mis conciudadanos, de aceptarla con indulgencia en obsequio de miras tan laudables. Yo soy, granadino, un hijo de la infeliz Caracas, escapado prodigiosamente de en medio de sus ruinas físicas, y políticas, que siempre fiel al sistema liberal, y justo que proclamó mi patria, he venido a seguir aquí los estandartes de la independencia, que tan gloriosamente tremolan en estos Estados.

Permitidme que animado de un celo patriótico me atreva a dirigirme a vosotros, para indicaros ligeramente las causas que condujeron a Venezuela a su destrucción...". ${ }^{13}$

Los términos 'conciudadanos', 'patriótico celo' y otros comienzan a usarse en estos primeros años del siglo XIX con referencia a al lugar de nacimiento o de residencia, especialmente en las revueltas coloniales, entre la clase de los criollos. Muchas veces, para justificarlas.

En 1815 Bolívar empleaba con frecuencia esas palabras, para referirse a su Venezuela natal.

"Sensible como debo, al interés que usted ha querido tomar por la suerte de mi patria, afligiéndose con ella por los tormentos que padece, desde su descubrimiento hasta estos últimos períodos, por parte de sus

13. S. Bolívar, Manifiesto de Cartagena, 1812 
destructores los españoles, no siento menos el comprometimiento en que me ponen las solícitas demandas que usted me hace, sobre los objetos más importantes de la política americana". ${ }^{14}$

Bolívar, un genuino representante de la clase de los criollos, incluso de familia con una cierta fortuna y que tomó partido por la causa de la independencia, hace de América su patria, como lo expresa en su Carta de Jamaica de 1815. Ideas similares se encontrarán en el pensamiento de José Gervasio Artigas en 1812 y de José de San Martín. Pero fuera de ellos, donde la palabra tenía los límites del continente, la 'patria' significó siempre un concepto regional estrecho y, a menudo, confundido con los intereses de clase.

Las revueltas se originaron en una efervescencia de los vecinos que cuestionaron a las autoridades coloniales y encontraron en el Cabildo el espacio propicio para manifestarse. El Cabildo, como institución que guardaba los derechos de los vecinos, con un fuerte tinte localista, recibieron con los brazos abiertos estos cuestionamientos. Muchos de ellas convocaron el pueblo al son de las campanas que llamaban a 'cabildo abierto'. Estas revueltas se plasmaron en actas. Analicemos brevemente algunas de ellas.

Casi todos los movimientos que cuestionaban el sistema colonial a principios del siglo XIX se originaron en las ciudades ${ }^{15}$, y en ellas tuvieron su principal radio de acción. Desde allí se extendieron con frecuencia a otras ciudades y luego a los sectores rurales, donde muchas veces fue necesario emplear la violencia para lograr la adhesión. Los intereses locales no admitían fácilmente movimientos impuestos desde la capital. Detengámonos por un momento en esas revueltas que terminaron en independencias.

\section{La revuelta de 1811 en San Salvador}

Detengámonos por un momento en la revuelta de San Salvador del 5 de noviembre 1811, y analicemos las demás revueltas desde esta óptica. Comencemos por una brevísima síntesis de los sucesos de San Salvador. Demos primeramente la palabra a Peccorini Letona, ahora deteniéndonos en el Preámbulo de su trabajo que nos sirve de guía en esta parte:

"En 1811, en efecto, el Intendente Don Antonio Gutiérrez de Ulloa tuvo que hacer frente a un motín popular suscitado por la noticia del encarcelamiento del Pbro. Don Manuel Aguilar y atizado por el descontento popular con motivo de la pésima situación tributaria. La furia del pueblo se ensañó contra las vidas y las propiedades de los españoles 'europeos' y lo llevó a elegir él mismo nuevo Ayuntamiento y nuevo intendente. Los que luego habrán de aparecer como

14. S. Bolívar, Carta de Jamaica.

15. Cuando los movimientos alcanzaron a los sectores rurales adquirieron una gran efervescencia y, con frecuencia, una gran radicalidad, como en los casos del movimiento de Túpac Amaru en el Virreinato del Perú en la segunda mitad del siglo XVIII, o el de los 'llaneros' de José Antonio Páez en Venezuela, en las primeras décadas del siglo XX. Sin embargo, estos casos no fueron frecuentes. 
los próceres de nuestra Independencia -los Delgado, los Arce, los Fagoaga, los Rodríguez y los Castillo, todos ellos españoles 'americanos'- aparentemente intervinieron en esta ocasión únicamente como pacificadores, si bien resultaron electos por el pueblo para los cargos de gobierno". ${ }^{16}$

La Intendencia de San Salvador, ubicada en el Reino de Guatemala, contaba en esos momentos con 4.729 españoles 'peninsulares' y 'americanos'; 71.175 indios y 89.374 mulatos, entre los que hay que presuponer a mestizos, pardos, ladinos y negros, según el informe del Intendente Gutiérrz y Ulloa de 1807, que ya citamos. ${ }^{17}$ La mayoría de éstos residía en San Salvador, la capital de la Intendencia. Sin embargo, es necesario considerar también la existencia de otras ciudades de una cierta importancia, y con ello, representantes de ciertos intereses locales, como San Miguel y Santa Ana, ambas fundadas ya en el siglo $\mathrm{XVI}$, como San Salvador, y que algunas veces hicieron expreso su localismo frente a la capital de la Intendencia. Se repetían aquí las mismas aprensiones de San Salvador con respecto a la capital del Reyno, Guatemala.

Demos la palabra ahora a Sajid Herrera para una breve crónica de los hechos. "El 4 de noviembre corrió el rumor en la ciudad de San Salvador de que el cura Manuel Aguilar fue arrestado y que el intendente Antonio Gutiérrez y Ulloa tomó medidas preventivas, como permitir a los españoles que se armaran, ante cualquier alzamiento popular. Pero lo sospechado ocurrió. Ese mismo día los alcaldes de los barrios de la ciudad y algunos líderes criollos, parientes de los curas Aguilar, movilizaron a muchas personas para protestar en contra del gobierno. Los líderes criollos (Bernardo Arce, Manuel José Arce, Mariano Fagoaga, José Matías Delgado, entre otros) eran de la idea de que el problema podía solucionarse no con disturbios, los cuales ya comenzaban a darse, sino a través de un cabildo. Y así se hizo. Al día siguiente, al toque de la campana fue convocada una multitud de personas en la plaza mayor. Mientras el intendente Gutiérrez y Ulloa se encontraba confinado en su propia casa por temor a ser agredido y mientras algunos individuos intentaban sustraer las pocas armas que se había en el depósito real, unos funcionarios le pidieron al cura de la ciudad, José Matías Delgado, que apaciguara los ánimos". ${ }^{18}$

Nuestro autor se hace eco de las interpretaciones que sostienen el descontento popular y la participación de 'muchas personas' de los barrios, poniendo en evidencia el liderazgo de los alcaldes barriales, y presenta a los líderes criollos en su papel de apaciguadores de la revuelta. Fueron ellos quienes supieron

\footnotetext{
16. Peccorini Letona, Francisco, La Voluntad del Pueblo en la Emancipación de El Salvador, Dirección de Publicaciones e Imprasos, San Salvador, 1972, pág. 7.

17. Antonio Gutiérrez y Ulloa, Estado General de la Provincia de San Salvador (año de 1807), Dirección de Publicaciones e Impresos, San Salvador, 1962.

18. Herrera, Sajid Alfredo, 1811. Relectura de los levantamientos y protestas en la Provincia de San Salvador, en Las independencias iberoamericanas, Comisión Organizadora de las Conmemoraciones de 2010, Edición del Instituto Nacional de Estudios Históricos de las Revoluciones de México, México, 2010, pág. 128.129.
} 
encauzar el descontento popular y la manifestación, más o menos espontánea, quedándose -aunque por poco tiempo-, con el poder político.

La revuelta de 1811 estalló ante un sentimiento popular confuso: la reacción ante la noticia del arresto en Guatemala de un sacerdote local. Ésta fue a su vez avivada por la noticia de que el Intendente Gutiérrez y Ulloa había armado a los odiados españoles peninsulares de la ciudad, lo que hizo suponer que éstos estaban dispuestos a defenderse con las armas ante las amenazas contra sus propiedades, amenaza que probablemente no estaba en la mente de ninguno de los revoltosos, pero sí, quizá, en el temor de los españoles peninsulares y de los criollos. Sin duda, el sentimiento de verse acusados de algo que nadie pensaba provocar, pero quizá en el fondo temían, y que desvirtuaba las razones del levantamiento, dio más razones al movimiento.

Los rumores, frecuentes en épocas de efervescencia popular, hicieron de un rumor una verdad, supusieron un atentado contra la vida del cura Vicario de la ciudad, el Presbítero José Matías Delgado e hicieron de ello una causa que hería el sentimiento de toda la población de la ciudad. Ante esto, los alcaldes de los barrios, probablemente los verdaderos y anónimos líderes del movimiento, convocaron a la gente a congregarse ante la residencia de Delgado y ante el Cabildo. En esos momentos, probablemente, el confuso sentimiento popular, cercano al temor y la indignación, y reviviendo antiguas marginaciones y reclamos no atendidos, se dirigió hacia las autoridades coloniales que representaban a la capital.

Es probable que la intervención de los criollos haya que buscarla en estos momentos, cuando las efervescencia popular llega al espacio donde los criollos habían ejercido sus derechos desde hacía tres siglos: el cabildo. Cuando la efervescencia popular se trasladó de la residencia del presbítero Delgado al edificio del Cabildo, la presencia en el movimiento de una clase ligada a los privilegios y al sistema se hace evidente y toma protagonismo, a la par que añade los viejos resquemores contra la capital, despertando antiguas exigencias insatisfechas de autonomía y libertades, dirigiendo el sentimiento de descontento popular hacia las autoridades coloniales.

'Viva el Rey y muera el mal gobierno': la frase que intentaba expresar el descontento popular expresaba ahora la reacción contra las autoridades: no se ponía en tela de juicio el sistema en el cual algunos -los criollos entre ellosdetentaban privilegios, sino la ineptitud de quienes debían hacerlo funcionar y repartían mal, precisamente, esos privilegios: las autoridades coloniales nombradas en la capital del Reyno, Guatemala. Ya el descontento popular había quedado atrás y los habitantes de los barrios podían irse a sus casas de los suburbios. Ya el liderazgo de la revuelta había pasado de manos de los alcaldes de los barrios a los criollos, con quienes las autoridades coloniales trataban ahora para solucionar el descontento y decantar la efervescencia que ponía en peligro 'las propiedades y caudales'. 
Cuando el Intendente Gutiérrez y Ulloa pidió que alguien hablara en nombre de los manifestantes, Manuel José Arce, un criollo de familia con intereses en la producción del añil, tomó ese lugar, porque el

“... dho. Sor Ynte. ... este mismo Sor. no pudiendo entender sus solicitudes (de los manifestantes) que entre la confusión y el trastorno de la vocería de muchos, se hacían habló al Pueblo, para que nombrase a uno que metodicamte. le expusiese, lo que pedia con desorden". ${ }^{19}$

El Intendente nombrado por la capital, un español peninsular, prefirió entenderse con un criollo que con los manifestantes y dejar de lado la vieja costumbre colonial de repimir las revueltas. Probablemente no estaba seguro de sus resultados ni de las fuerzas con que contaba. Pñrobablemente, se sentía más seguro con alguien con quien compartía privilegios y puntos de vista. Y la revuelta depuso sin violencia a las autoridades peninsulares haciendo uso de la idea de la soberanía popular, y puso a otros criollos en su lugar.

Las revueltas americanas, si bien a veces tuvieron nacimientos espontáneos, como explosiones provocadas por la irritación popular, tuvieron siempre dirigentes criollos, como en el caso de las revueltas del 5 de noviembre de 1811, la del 24 de enero de 1814 y de la mayoría de las revueltas hispanoamericanas del siglo XIX. Ya sea porque los manifestantes los veían como líderes naturales, ya porque eran los únicos que estaban en condiciones de ser escuchados por las autoridades españolas o porque los mismos criollos lo buscasen, el hecho es que generalmente encontraremos criollos al frente de las manifestaciones.

Veamos este testimonio para el caso de la revuelta de 1811 en San Salvador:

"San Salvor. diciembre $1^{\circ}$. de diciembre de 1814 ... que medio desde junio de 8050 (sic) en qe. me posesione de aquella Yntendcia. hasta 4 "de Nove. de 1811" en cuya noche se empezo a manifestar la insubordinacn. é inquietud Popular de aquella Ciudad: que desde el día 5" siguiente. el 19" en qe. me traslade con mi familia al Comvto. De Sto. Domingo dejando el mando con arreglo a Ordenza. se condujo al expresado Arce con el carácter de representande (sic) del Pueblo, en los términos qe. constan del ofo..."2o

Es el propio José Bustamante y Guerra, Capitán General del Reyno de Guatemala, quien declara en favor de Arce y lo presenta como representante del Pueblo. En este caso, la palabra 'pueblo' está referida a los manifestantes: los pobladores de los suburbios de San Salvador, convocados por sus alcaldes, que habrían concurrido a custodiar la casa del. Cura Vicario de la ciudad, José Matías Delgado.

19. Declaración de Manuel José Arce del 17 de enero de 1815, en M. A. García, Procesos por infidencia... pág. 20.

20. Declaración de José Bustamante y Guerra del 1 de diciembre de 1814, en García, M. A., Procesos por infidencia.., pág. 19. 
Detengámonos un momento en las palabras del Capitán General. La alusión a 'insubordinación e inquietud popular' expresan, probablemente, la forma como se percibió la revuelta por parte de las autoridades del Reyno: la revuelta habría sido expresión de la 'inquietud popular' -concepto que podría llevar implícita la idea de desorden y manifestación de descontento y reclamos-, y de insubordinación, que sin duda implicaba el cuestionamiento del sistema. Probablemente, las autoridades coloniales vieron en la revuelta una radicalidad mayor que la que la que en realidad le dieron los criollos.

Notemos la participación del pueblo como primeros protagonistas de la revuelta, especialmente en en sus primeros momentos. Sigamos leyendo a Herrera:

"Por ello, a petición de los criollos, se eligió como alcalde de primer voto a Bernardo Arce y, a petición del intendente Gutiérrez y Ulloa, se le permitió a 'la plebe' elegir a su representante. Resultó como tal Manuel José Arce, hijo de Bernardo, ambos parientes de los curas Aguilar (Bernardo era primo de éstos). En el día 5 se impuso, entonces, la presión popular..."21

Si nos atenemos a la letra del documento, el hecho de que 'la plebe' haya elegido como representante suyo ante las autoridades ante las cuales querían presentar sus reclamos, a uno que no fuera de su clase habla claramente de la influencia y del prestigio de los criollos ante los habitantes de los suburbios. $Y$ cuando este representante tuvo que presentar los reclamos, presentó los propios: los de aquéllos que lo habían elegido, probablemente, no los conocía y sin duda no estaban definidos.

Creemos necesario indicar que por 'pueblo' o 'plebe' hay que entender en este caso las personas de clases medias ligadas de alguna manera a los criollos: los criollos pobres, los que ejercían oficios, los ladinos y, probablemente, los negros libres o mulatos que se habían logrado un cierto lugar en la sociedad colonial por su trabajo. Todos ellos ocupaban el amplio estrato intermedio entre los privilegiados, los españoles peninsulares y los españoles americanos, y los indios. Los indígenas no tienen cabida en este asunto.

Si el pueblo supo iniciar las revueltas, es evidente que lo hizo sin preparación y en forma espontánea. Sin duda, existía un generalizado descontento que subyacía en la conciencia colectiva desde hacía siglos, acentuado en los últimos años y que no supo organizar su manifestación. Por otra parte, esta confusa conciencia colectiva no tenía aún definidas sus necesidades, más allá de los reclamos por las excesivas cargas fiscales, la burocracia administrativa colonial o los excesivos precios de algunos alimentos básicos.

Sin duda, en algunos casos por lo menos, los habitantes de los suburbios participaron en las revueltas guiados e incitados por los alcaldes de los barrios,

21. Herrera, Sajid Alfredo, 1811. Relectura de los levantamientos y protestas en la Provincia de San salvador, en Las independencias iberoamericanas, Comisión Organizadora de las Conmemoraciones de 2010, Edición del Instituto Nacional de Estudios Históricos de las Revoluciones de México, México, 2010, pág. 129. 
como en el caso de la revuelta del 5 de noviembre de 1811 en San Salvador. Y sin duda, también, los movimientos iniciados por las mayorías mestizas e indígenas fueron, después del movimiento inicial, aprovechados por la clase dirigente de los criollos para presentar sus propios reclamos como los intereses de las mayorías. Cuando los criollos lograron la dirección de los movimientos, después de las primeras manifestaciones -alguno de esos movimientos, incluso, tendría la pretensión de la independencia política-, lograron también la moderación de los reclamos y la des-radicalización de los movimientos, terminando en una simple petición de disminución de los impuestos exigidos.

Veamos en este testimonio tomado del juicio que se siguió a Manuel José Arce, el uso de las palabras pueblo, estado, nación, vecinos y patria:

“... O se le hizo últimamente cargo de haber (tomado parte en) la execrable y escandalosa Junta que se tubo en el Cavildo por los mismos facciosos en acción de gracias que se iban realizando sus delincuents proyectos dirigidos todos contra el estado, contra el Público, contra los vecinos Europeos y demás que no eran de su partido contra su patria y contra su nación...".22

Pero vayamos nuevamente a los documentos. Las actas de los cabildos que hicieron de seno, en la gran mayoría de los casos, a los movimientos revolucionarios de la América española de principios del siglo XIX refieren la palabra 'pueblo' y otros vocablos cercanos con diversos significados. Detengámonos en algunos de estos casos.

El uso del concepto 'pueblo' en los movimientos revoltosos de principios del siglo XIX

Son numerosos los documentos que presentan la palabra 'pueblo' para designar a los participantes de los movimientos de principios del siglo XIX en las colonias españolas en América. Las menciones más comunes hacen referencia a dos situaciones. La primera de ellas, a la presencia de los pobladores que se manifiestan en la plaza de armas de cada ciudad y que hacía de centro cívico y político de las ciudades coloniales, como en el caso de la declaración de la independencia de Guatemala en 1821:

“... oído el clamor de Viva la Independencia, que repetía de continuo el pueblo que se veía reunido en las calles, plaza, patio, corredores y antesala de este palacio..."23

La segunda de esas menciones hace referencia a la representatividad de los diputados a los congresos que declararon las independencias o instalaron juntas de gobierno, como en el caso de la instalación de la Junta Suprema de Quito de 1809, ésta con una clara alusión a los pobladores de los barrios de la ciudad:

22. Cargos contra Manuel José Arce del 17 de abril de 1816, en García, M. A., Procesos por infidencia.., pág. 53.

23. Acta de declaración de la independencia de Guatemala. 
"Nos, los infrascritos diputados del pueblo, atendidas las presentes circunstancias críticas de la nación, declaramos solemnemente...

Los del barrio de San Sebastián elegimos ynombramos por representantes de él a don Manuel Zambrano, ...Los del barrio de San Roque elegimos y nombramos por representantes de él al Marqués de Villa Orellana ... Los del barrio de San Blas elegimos y nombramos por representantes de él a don Manuel de Larrea ... Los del barrio de Santa Bárbara elegimos y nombramos por representantes de él al Marqués de Miraflores ... Por el barrio de San Marcos elegimos y nombramos por representantes de él a don Manuel Mateu ..." 24

En la Carta de Jamaica de 1815, Bolívar emplea al menos 4 veces la palabra 'pueblo', siempre haciendo alusión a situaciones gloriosas:

"El reino de Chile, poblado de ochocientas mil almas, está lidiando contra sus enemigos que pretenden dominarlo; pero en vano, porque los que antes pusieron un término a sus conquistas, los indómitos y libres araucanos, son sus vecinos y compatriotas; y su ejemplo sublime es suficiente para probarles, que el pueblo que ama su independencia, por fin la logra".

“QQué demencia la de nuestra enemiga (España), pretender reconquistar América, sin marina, sin tesoros y casi sin soldados! Pues los que tiene, apenas son bastantes para retener a su propio pueblo en una violenta obediencia, y defenderse de sus vecinos".

"Es más difícil, dice Montesquieu, sacar un pueblo de la servidumbre, que subyugar uno libre”..

"Los más de los hombres han perecido por no ser esclavos, y los que viven, combaten con furor, en los campos y en los pueblos internos hasta expirar o arrojar al mar a los que insaciables de sangre y de crímenes, rivalizan con los primeros monstruos que hicieron desaparecer de la América a su raza primitiva”.

Las tres primeras referencias hacen alusión a los pobladores; la cuarta hace alusión a un espacio geográfico: 'en los campos y en los pueblos internos'.

Mientras que en su Manifiesto de Cartagena de 1812, sólo una vez se encuentran las palabras 'pueblo' y 'patria':

Tal era el verdadero estado de la Confederación. Cada provincia se gobernaba independientemente; $y$, a ejemplo de éstas, cada ciudad pretendía iguales facultades alegando la práctica de aquéllas, y la 
teoría de que todos los hombres, y todos los pueblos, gozan de la prerrogativa de instituir a su antojo, el gobierno que les acomode".

"Yo soy granadino, un hijo de la infeliz Caracas, escapado prodigiosamente de en medio de sus ruinas físicas, y políticas, que siempre fiel al sistema liberal, y justo que proclamó mi patria, he venido a seguir aquí los estandartes de la independencia, que tan gloriosamente tremolan en estos Estados". ${ }^{25}$

En la primera cita, el concepto de 'pueblo' alude a la persona en forma individual, como integrante de un estado nacional. Podría asimilarse el concepto al de 'ciudadano', aún en un estado incipiente: en esos momentos ni siquiera existía como estado independiente. En la segunda, la alusión a 'patria' se refiere una institución nacional.

Estas seis referencias de Simón Bolívar están privadas de connotaciones de élite: no se encuentran aquí alusiones a que la palabra 'pueblo' pueda tener otras limitaciones en su acepción que las que marca el espacio geográfico. Bolívar era un criollo nacido en una familia de la más pura aristocracia caraqueña; sin embargo, su concepto de 'pueblo' no está restringido al marco de su clase social. Sin embargo, no será ésta la idea que estaba en la cabeza de la mayoría de los criollos.

Todas estas referencias le sirven a Bolívar para justificar, en los dos documentos, si bien diversos en el tiempo y ambos cercanos al año de la primera revuelta centroamericana, los diversos movimientos revoltosos del siglo XIX, algunos de los cuales -como dijimos arriba-, no tenían la independencia como fin último; más bien, ésta fue una intención que se sumó después a estos procesos.

La palabra 'patria' dio también lugar a interpretaciones diversas y en algunas ocasiones, en coincidencia con el significado de la palabra 'pueblo'. El mismo Bolívar en su Carta de Jamaica la usa tres veces:

"Sensible como debo, al interés que usted ha querido tomar por la suerte de mi patria..."

“...el reino de Quito que con la mayor dificultad contienen sus enemigos, por ser fuertemente adicto a la causa de su patria; y las provincias...

"A pesar de todo, los mejicanos serán libres, porque han abrazado el partido de la patria, con la resolución de vengar a sus pasados, o seguirlos al sepulcro". ${ }^{26}$ 
Unos años antes, en 1810, la ciudad de Buenos Aires, en el extremo sur del Imperio colonial español, por muchos años al margen de los acontecimientos decisorios del Imperio y de tardía importancia en el Imperio -el Virreinato del Río de la Plata fue creado creado recién en 1776-, asiste a una revuelta urbana de vecinos de la ciudad, desde hace sólo 34 años capital de un virreinato. Ya desde los intentos de invasión por parte de los soldados ingleses en los años 1806 y 1807, los vecinos de la ciudad habían dado prueba de su capacidad de organización y decisión, rechazando a los soldados ingleses en la propia ciudad. Sin duda, ello les dio una gran confianza en sí mismos, les ayudó a definirse como clase tomando conciencia de ello y de sus intereses comunes, les obligó a definir los liderazgos y a generar un sentimiento de desconfianza hacia la administración colonial española, inoperante en el caso de las invasiones.

En 1810, la clase de los criollos de Buenos Aires era ya una clase sólidamente definida, con grandes influencias y espacios de decisión en el gobierno del virreinato y con una gran confianza en sus propias fuerzas. Esta conciencia había tenido oportunidad de templarse durante las invasiones inglesas: el rechazo del ejército inglés que había intentado invsadir la capital del Virreinato había sido obra de los criollos. Las autoridades coloniales, por su parte, habían caído en un profundo descrédito por su secular inoperancia, y, especialmente, por su actuación durante las invasiones inglesas.

Al estallar la crisis, ya en 1809, los criollos tomaron la iniciativa y dirigieron las manifestaciones hacia sus intereses. En una sociedad donde los elementos indígenas estaban prácticamente ausentes, probablemente esta solidez criolla anuló la capacidad de manifestarse de los mestizos y negros. En 1810 los criollos llenaban la plaza de armas de Buenos Aires, donde los mestizos y negros estaban ausentes. Si bien esto se debió en buena parte a que las entradas estaban controladas por las milicias criollas, mucho tuvo que ver el dinamismo de los criollos que, seguros de sí mismo, habían tomado ya desde hacía tiempo el control de la ciudad y no permitieron las manifestaciones de la gente de los suburbios. Todo esto presenta similitudes y contrastes con la revuelta sansalvadoreña de 1811.

El acta del cabildo de Buenos Aires del 25 de mayo de 1810 arroja datos sumamente interesantes con respecto al uso de los conceptos que queremos definir. Hay por lo menos siete alusiones a los conceptos de 'pueblo' y 'vecinos' en el acta; no se menciona la palabra 'patria', confundida aquí y en la mente de los protagonistas de la revuelta, con el concepto de 'vecinos'. Para los protagonistas de la revolución de mayo de 1810 en Buenos Aires la patria son los mismos vecinos de la ciudad. De todas las revueltas hispanoamericanas, probablemente la de Buenos Aires es la que más se aleja del concepto de revolución, la que más distante está de la radicalidad. Sin embargo, los cambios de 1810 nunca estuvieron en peligro.

Veamos algunos de los conceptos que mencionábamos. 


\begin{abstract}
"(los integrantes del Cabildo) ... se enteraron de una representación que han hecho a este Excmo. Cabildo un considerable número de vecinos, los Comandantes y varios Oficiales de los Cuerpos voluntarios de esta Capital, por si y a nombre del Pueblo, en que indicando haber llegado a entender que la voluntad de éste resiste la Junta...". ${ }^{27}$
\end{abstract}

De acuerdo a la letra del documento, el Cabildo recibe una representación de 'un considerable número de vecinos': los vecinos son los habitantes de la ciudad, dentro de lo que estaba definido como tal en ese entonces, quienes tenían propiedad en ella: los criollos. Estos vecinos hablan 'por sí y en nombre del Pueblo', según el documento: o sea, asumen la representatividad de los numerosos pobladores de los suburbios, de las poblaciones cercanas y de quienes no tenían propiedad dentro de la ciudad. Es en nombre de ellos y en nombre propio, entonces, que presentan una petición que incluye un cambio de autoridades. Los vecinos de Buenos Aires, probablemente en la ofuscación del momento, asumen la representación de todos los habitantes del Virreinato sin que nadie se la haya otorgado.

"quiere que este Excmo. Cabildo proceda a hacer nueva elección de los Vocales que hayan de constituir la Junta de Gobierno, y han de ser los señores D. Cornelio de Saavedra, Presidente de dicha Junta y Comandante General de armas, el Dr. D. Juan José Castelli, el Dr. D. Manuel Belgrano, D. Miguel Azcuénaga, Dr. D. Manuel Alberti, D. Domingo Mateu, y D. Juan Larrea, y Secretarios de ella los Doctores $D$. Juan José Paso y D. Mariano Moreno; cuya elección se deberá manifestar al Pueblo por medio de ...". 28

El documento hace alusión a la Junta de Gobierno creada unos días antes y que había conservado las autoridades coloniales con el agregado de algunos representantes criollos. El 22 de mayo, una asonada vecinal había cuestionado las autoridades españolas, exigiendo al Cabildo un nuevo gobierno leal al rey español. La jurisdicción de los cabildos era municipal; no tenían, por lo tanto, jurisdicción para deponer una autoridad virreinal. Sin embargo, el de Buenos Aires lo hizo: depuso al virrey don Baltasar Hidalgo de Cisneros, nombrado por la Junta Central de Sevilla en 1809, pero nombró una Junta de Gobierno presidida por el mismo virrey. El 25 de mayo, 'un considerable número de vecinos ... por sí y a nombre del pueblo...', exigió la renuncia de la Junta anterior y el nombramiento de una nueva, presentando incluso los nombres de quienes debían integrarla: los integrantes de la nueva Junta de Gobierno estaban ya definidos: dos militares, cuatro abogados, dos comerciantes y un sacerdote. Esta decisión debía ser comunicada al 'Pueblo' por medio de un bando que debía emitir el Cabildo. 
Hay algunos conceptos más que merecen ser tenidos en cuenta en esta acta.

“...porque esta es la manifiesta voluntad del pueblo. Y los S.S. habiendo salido al Balcón de estas Casas Capitulares, y oído que el Pueblo ratificó por aclamación el contexto de dicho pedimento o representación, después de haberse leído por mi en altas e inteligibles...". ${ }^{29}$

Es necesario tener presente que las milicias controladas por los criollos, que habían tenido un intenso protagonismo años antes, con las invasiones inglesas, hecho que les había otorgado inmenso prestigio ante los vecinos, habían controlado los accesos a la plaza de armas donde estaba el edificio del Cabildo. Por lo tanto, el ‘Pueblo' que 'ratificó por aclamación', las nuevas autoridades, entre las cuales ya no estaba el Virrey, estaba conformado por las personas que las milicias habían dejado entrar a la plaza.

Quienes tenían acceso al Cabildo -los criollos- decidían acerca de la 'voluntad del pueblo', y a éste debía ser comunicada la decisión de la nueva Junta de Gobierno. Un verdadero golpe de estado en nombre del pueblo. Y continúa el acta que

"Lo III: que luego que los referidos S.S. presten el juramento, sean reconocidos por depositarios de la Autoridad Superior del Virreynato por todas las corporaciones de esta Capital y su vecindario..." 30 .

La nueva Junta debía ser reconocida por 'todas las corporaciones de esta capital y su vecindario' o sea, los criollos, que de esta forma se erigían como los representantes del pueblo, y por lo tanto, ante quienes debían rendir cuentas las nuevas autoridades. Los criollos porteños se transformaban así en los nuevos detentadores del poder político.

Esto que decimos se acentúa con la disposición siguiente:

"Lo V: que aunque se halla plenísimamente satisfecho de la honrosa conducta y buen procedimiento de los S.S. mencionados, sin embargo, para satisfacción del Pueblo se reserva también estar muy a la mira de sus operaciones y caso no esperado que faltasen a sus deberes, proceder a la deposición ...":

los criollos quedaban 'muy a la mira' de las operaciones de la nueva Junta con la facultad de deponer a los miembros que, a su juico, no cumpliesen con lo que debían hacer:

"Lo VI: que la nueva Junta ha de celar sobre el orden y la tranquilidad pública, y seguridad individual de todos los vecinos, haciéndosele como desde luego se le hace responsable de lo contrario." 31 
Los vecinos determinaban, como una de las funciones principales de la nueva Junta, velar por la tranquilidad y seguridad de todos los vecinos. También aquí, como en casi todas las revueltas de principios del siglo, quedaba en evidencia el temor que sentían los criollos al caos y al consecuente daño a sus propiedades que podría derivarse de ello.

Diez años más tarde, el acta de la declaración de la independencia de Guayaquil expresaba conceptos similares:

"En la ciudad de Santiago de Guayaquil, a nueve días del mes de octubre de mil ochocientos veinte años ... Que habiéndose declarado la Independencia, por el voto general del pueblo, ... y, debiendo tomar en consecuencia, todas las medidas que conciernen al orden político, en circunstancias que este necesita de los auxilios de los principales vecinos,...".32

El Cabildo de Buenos Aires, en 1810 había convocado a 'la parte más sana y principal' del vecindario para llegar a esta situación; pero la Junta era consciente del alcance local de sus decisiones. Previendo un congreso de más amplia representatividad regional, disponía que

“...los respectivos Cabildos de cada uno convoquen por medio de esquelas la parte principal y más sana del vecindario, para que formado un congreso de solos los que en aquella forma hubiesen sido llamados, elijan sus representantes..." 33 ,

pero se aseguraba que los representantes a este congreso perteneciesen a su misma clase social: es siempre 'la clase más sana y principal' quien toma las decisiones en las revueltas.

En la revuelta de San Salvador del 5 de noviembre de 1811, -en la que, sin embargo, no hay un acta del Cabildo de ese día pero sí una 'relación histórica' un tanto informal-, los criollos se quedaron con el poder político: quienes asumirían los cargos administrativos que ostentaban hasta ese momento las autoridades coloniales serían los criollos ligados en esos años a la producción del añil. Las similitudes con la revuelta de Buenos Aires de 1810 son grandes.

Diez años después de la asonada de 1811, en Guatemala los representantes de las diferentes regiones del Reyno de Guatemala declaran la independencia. El acta que refiere este hecho es sumamente significativa en el empleo de la palabra 'pueblo'. Detengámonos un momento también en este documento.

En el acta se encuentra seis veces la palabra 'pueblo'; sin embargo, en el mismo documento no siempre encierra el mismo sentido.

32. Acta de la declaración de la independencia de Santiago de Guayaquil, 9 de octubre de 1820 .

33. Cabildo de Buenos Aires, Acta del 25 de mayo de 1810. 
"Siendo públicos e indudables los deseos de independencia del Gobierno Español, que por escrito y de palabra ha manifestado el pueblo de esta capital...":

aquí el 'pueblo' son los habitantes de la ciudad de Guatemala que se han manifestado en favor de la independencia.

“...y oído el clamor de Viva la Independencia, que repetía de continuo el pueblo que se veía reunido en las calles, plaza, patio, corredores y antesala de este palacio...",

con el mismo significado: la población que gritaba vivas a la independencia y que se había reunido en las calles cercanas al Palacio de los Capitanes Generales y en su patio, corredores y antesala.

"Que siendo la independencia del Gobierno Español la voluntad general del pueblo de Guatemala...",

donde el concepto parece estar referido a toda la población del Reyno de Guatemala, interpretado por los firmantes del acta,

"el Sr. Jefe Político lo mande publicar para prevenir las consecuencias, que serian temibles en el caso de que la proclamase de hecho el mismo pueblo"34:

En este último caso, sin duda, hay un distanciamiento del concepto como estaba entendido en las citas anteriores.

En ellas, de la lectura del texto se puede entender que el pueblo había manifestado su deseo de independencia y sus representantes estaban dispuestos a acatar ese deseo. Según esta acta, es necesario evitar las consecuencias - i'que serían temibles'!-, que se derivarían de la declaración de independencia por parte del pueblo: el mismo pueblo cuya voluntad se pretende llevar a cabo declarando la independencia. Es necesario preguntarse por un momento, además, en quién sufriría esas temibles consecuencias: nos animamos a contestar: los firmantes del acta: los criollos de San Salvador y de las otras regiones representadas en el congreso.

Ahora, sin embargo, sorprende esta mención a las consecuencias temibles que podrían derivarse de la acción directa del pueblo. Sin duda, los firmantes del acta sienten temor a perder el control del movimiento, y con ello, a los posibles resultados de una independencia declarada desde otros lugares políticos, otros intereses y otros modelos. 
Pensamos que no estaremos errados si afirmamos que los mismos criollos que firmaron el acta de independencia en 1821, fueron los que intentaron las revueltas de 1811 y 1814: cambiaron algunos nombres -otros continúan-, pero los intereses son los mismos.

El artículo $13^{\circ}$ del acta contiene además, dos alusiones al concepto 'pueblo', en los que no nos detenemos ahora.

En el texto de la declaración de independencia de Estados Unidos en 1776, texto que sin duda han tenido entre manos quienes firmaron el acta de 1821, la palabra 'pueblo' aparece cinco veces, pero el análisis que se puede hacer de ello arriba a conclusiones distintas.

El pueblo, en este texto, tiene derecho a disolver vínculos políticos:

"Cuando en el curso de los acontecimientos humanos se hace necesario para un pueblo disolver los vínculos políticos que lo han ligado a otro...";

reformar y abolir formas de gobierno destructoras de las verdades proclamadas en el escrito:

"cuando quiera que una forma de gobierno se haga destructora de estos principios, el pueblo tiene el derecho a reformarla o abolirla e instituir un nuevo gobierno";

tiene derechos explícitos y reconocidos que pueden llegar a ser violentados:

"Ha disuelto las Cámaras de Representantes una y otra vez, por oponerse en forma decidida a sus Intromisiones en los Derechos del Pueblo";

está representado en el gobierno por medio de los estamentos legislativos:

“...ha rehusado durante mucho Tiempo, luego de estas Disoluciones, motivar a que otros sean electos, por lo cual los Poderes Legislativos, incapaces de ser Aniquilados, han regresado sin restricciones al Pueblo para su ejercicio...", y

sufre hostigamientos por parte del rey y produce frutos que son apropiados por los funcionarios:

"Ha creado un Sinnúmero de nuevos Despachos, y enviado a nuestras tierras un Enjambre de Funcionarios para hostigar a nuestro Pueblo y apropiarse de sus Frutos". ${ }^{35}$

35. Declaración de independencia de Estados Unidos, 1776. 
Sin duda, todos estos conceptos habían sido leídos y tenidos en cuenta al momento de las revueltas americanas, tanto en San Salvador en 1811, 1814 y 1821 , como en Guatemala en el mismo 1821 y en las demás capitales americanas en donde surgieron revueltas o revoluciones o se declararon independencias a principios del siglo XIX. Las declaraciones de principios y las acusaciones hacia las autoridades cuestionadas adquieren grandes similitudes con éstas que hemos enunciado brevemente.

Detengámonos por un momento nuevamente en el año 1821. Después del 15 de setiembre, la noticia de la independencia llegó a El Salvador unos días después, y el 21 de ese mismo mes los integrantes del Cabildo de San Salvador

"dispusieron que en aquella hora concurrieran á este Ayuntamiento todos sus individuos, y se convocaron también a los jefes militares, al Sr. Cura Rector y Vicario, á los Prelados Regulares, á los vecinos principales de todas clases y que se excitará á todo el vecindario...".

Como se ve, el cabildo convocó a los jefes militares, al cura párroco de la ciudad, a los superiores de las órdenes religiosas y, también aquí, 'a los vecinos principales de todas clases', mientras se 'excita' a los vecinos a concurrir. Se va a hacer pública el acta del 15 de setiembre. Y

“Verificada la reunión, con numerosísimo pueblo...” ...

Llama la atención este brusco viraje en el relato del acta: se ha convocado a los 'vecinos principales', y sin embargo, la reunión se verifica 'con numerosísimo pueblo’.

Al correrse la noticia, la reunión se traslada a la iglesia parroquial, donde,

"entre vítores y aclamaciones del numeroso pueblo que le seguía”,(aquí, nuevamente, el 'numeroso pueblo')

se lee el acta de independencia. Luego, el Jefe Político exige que el alcalde le tome juramento porque

“así lo pidió el pueblo".

Se programa para más adelante el juramento del pueblo, y se le permite que exprese su júbilo:

"Se permitió al pueblo en desahogo del entusiasmado júbilo que no ha podido reprimir al ver conseguidos sus deseos, que continúe en sus regocijos con la honradez y moderación correspondientes". ${ }^{36}$ 
La palabra 'pueblo' está usada aquí tanto para referirse a las mayorías a las cuales se les permite que expresen su júbilo, como a los 'vecinos principales'. Nuevamente el concepto de vecindad hace referencia a la revuelta. Quedan fuera de estas manifestaciones las comunidades indígenas, los negros, los mestizos que viven fuera de la ciudad, quienes viven en los suburbios... En síntesis, quienes no pueden ser considerados como 'vecinos principales'.

En esos mismos años pero en otras latitudes, en Santiago de Guayaquil, en 1820 , se declaraba la independencia de Ecuador. Como siempre, el acta del cabildo refiere este hecho; en este caso, un acta sumamente breve que se limita a narrarlo sin mayores comentarios. Con todo, aparecen también aquí las palabras 'pueblo' y 'vecino' con significados similares a los que venimos planteando. En efecto, refiere el acta, en una cita que ya trajimos antes,

"Que habiéndose declarado la Independencia, por el voto general del pueblo, al que estaban unidas todas las tropas acuarteladas; y, debiendo tomar en consecuencia, todas las medidas que conciernen al orden político, en circunstancias que este necesita de los auxilios de los principales vecinos...". ${ }^{37}$

Nótese que para declarar la independencia se necesita del pueblo, pero para tomar las medidas que conciernen al orden público, se necesitan solamente los 'principales vecinos'. Nótese, además, un elemento que habíamos contemplado antes: las tropas unidas al pueblo: 'el voto general del pueblo al que estaban unidas todas las tropas acuarteladas', concepto que se refuerza más adelante:

\section{"por voluntad del pueblo y de las tropas..."}

Este hecho se aparta de la mayoría de las revueltas coloniales americanas, en las que las tropas estuvieron adictas a los gobernantes españoles y permanecieron pasivas, esperando órdenes de las autoridades superadas por los movimientos. Sin embargo, en las colonias desprotegidas militarmente o alejadas de los centros políticos, y en general allí donde las milicias habían suplantado con ventajas a las tropas de línea, la adhesión de estas fuerzas -vecinales, con escasa preparación militar y abundante entusiasmo cívico y local, más celosas de los intereses locales representados en lo criollos que de los intereses de toda la colonia. En estos casos como la periférica Buenos Aires, donde las tropas regulares fueron siempre escasas y donde las milicias tomaron su lugar adquiriendo experiencia durante las invasiones inglesas, éstas adhirieron rápidamente a las revueltas: sus jefes criollos eran precisamente, los principales cabecillas.

Posiblemente se puede entender aquí, también, el carácter netamente popular de unas fuerzas armadas que apoyan una revuelta contra el poder constituido, 
al lado de los vecinos. Se trata, sin dudas, de milicias de origen popular y seguramente con hondo arraigo ciudadano.

Y en esos mismos años, tan turbulentos, México declara su independencia tardíamente, en 1821. Se trata de un caso que no se ajusta a los parámetros que venimos presentando. El acta de declaración de independencia no está refrendada en el Cabildo y no menciona en ningún momento la palabra 'pueblo'. Solamente un primera alusión a la 'nación mexicana'. Sin embargo, los firmantes del acta son un reflejo de una rara alianza entre los criollos y los españoles peninsulares: entre ellos se encuentran dos obispos; nueve militares de alto rango, algunos de ellos ya retirados; dieciséis funcionarios de gobierno también de alto rango; un superior de una orden religiosa y cuatro curas de alto rango en la jerarquía de la Iglesia; cinco personas con títulos de nobleza; un hacendado, los cinco miembros del Consejo de Regencia, entre ellos el fututo emperador Agustín de Iturbide y Don Manuel Sánchez de Enciso, de quien no se tienen más noticias. ${ }^{38}$

Nuevamente aquí, los criollos, de larga trayectoria en el más antiguo virreinato español, esta vez en alianza con los españoles peninsulares, que aquí no tomaron una postura de rechazo radicalizado ante los cuestionamientos, tienen protagonismo en la revuelta. Entre los firmantes del acta, solamente don Manuel de Enciso, probablemente, no formaba parte de la clase de los criollos o de los españoles.

Una rápida mirada por la declaración de independencia del segundo virreinato español en América, el del Perú, arroja los mismos resultados. Aquí, la declaración de independencia no se produce a partir de una asonada urbana que comienza con una efervescencia popular; se produce, en cambio, cuando ya ha tenido lugar el triunfo militar, y ante la pregunta del general victorioso, el General San Martín, acerca de la opinión de los pobladores de la capital con respecto a la independencia. La pregunta no estaba exenta de una fuerte presión por parte del general victoriosos para declarar la independencia.

Los criollos de Lima, que habían tenido acceso a las 'nuevas ideas' y a las universidades ${ }^{39}$, pero que habían conservado siempre un tinte netamente aristocrático, adhieren rápidamente a la propuesta y declaran la independencia, pero el documento que la declara no se preocupa por hacer alusión a los deseos del pueblo acerca de la independencia. La breve acta de independencia no menciona en ningún momento las palabras 'pueblo' o 'patria', pero acerca algunas pistas.

Aquí, nuevamente es el cabildo quien convoca y en su interior se desarrollan los protagonismos:

38. Acta de independencia de México, 1821.

39. En la época de la colonia existieron en el Virreinato del Perú, dos universidades, la Universidad de San Marcos y la de San Antonio Abad del Cusco; y tres colegios mayores: el Colegio Máximo de San Pablo de Lima, el Colegio Mayor de San Felipe y San Marcos y el Colegio Real de San Martín. Además, en el Alto Perú, que desde 1776 pasó a integrar el Virreinato del Río de la Plata, la Universidad de San Francisco Xavier, de Chuquisaca. 
"En la ciudad de Los Reyes el quince de Julio de mil ochocientos veintiuno. Reunidos en este Excmo. Ayuntamiento...”.

Decíamos arriba que el Cabildo de Lima se caracterizaba por su talante criollo y aristocrático. De hecho, continúa el acta que estamos trayendo a colación:

"he impuesto de su contenido reducido a que las personas de conocida probidad, luces y patriotismo que habita en esta Capital, expresen si la opinión general se halla decidida por la Independencia, cuyo voto le sirviese de norte al expresado Sr. General para proceder a la jura de ella".

La alusión a 'su contenido' hace referencia al 'oficio del Excmo. Señor General en jefe del ejercito Libertador del Perú, Don José de San Martín’ donde preguntaba la opinión de los vecinos acerca de la independencia del Perú. Nótese que la convocatoria es a 'las personas de conocida probidad, luces y patriotismo': a ellas solamente se consultaría acerca de un hecho tan importante como la independencia política. La respuesta por parte de los consultados es positiva para el Cabildo de Lima. De hecho, el acta sigue afirmando

"Que la voluntad general está decidida por la Independencia del Perú" 40 .

Igualmente breve, pero sin duda menos aristocrática que el acta del Cabildo de Lima que acabamos de presentar, es el acta de la independencia emanada del Congreso de Anáhuac de 1813. Este Congreso, de raigambres con fuertes connotaciones indígenas y campesinas, originado en un movimiento que no había comenzado en una ciudad, además de declarar la independencia, ofreció un espacio propicio para la presentación del documento de José María Morelos, Sentimientos de la Nación. El marcado tinte democrático del Congreso, que contrastaba netamente con una sociedad mexicana marcadamente aristocrática, decidió la abolición de la esclavitud, declaró la independencia de México y formuló un documento con claros reflejos igualitarios.

Precisamente, este Congreso se pronuncia expresamente con respecto a la soberanía del pueblo, cosa que no sucedió con los demás documentos emanados de los movimientos revolucionarios, por lo menos, en la forma clara y directa que encontramos en éste, y sin lugar a las interpretaciones ambiguas que encontramos en otros:

"50 Que la Soberanía dimana inmediatamente del Pueblo, el que sólo quiere depositarla en el Supremo Congreso Nacional Americano, compuesto de representantes de las Provincias en igualdad de números." 
Se pronunció, asimismo, por la anulación de los privilegios:

"13 Que las leyes generales comprendan a todos, sin excepción de cuerpos privilegiados; y que éstos sólo lo sean en cuanto al uso de su ministerio."

La declaración de independencia es probablemente, la más radical de todas las independencias iberoamericanas, ya que corta de raíz los lazos con España:

"10 Que la América es libre independiente de España y de toda otra Nación, Gobierno o Monarquía, y que así se sancione, dando al Mundo las razones".,

a lo que hay que agregar esta otra declaración, que incluye además algunos principios:

"110 Que los Estados mudan costumbres, y por consiguiente la Patria no será del todo libre y nuestra, mientras no se reforme el Gobierno, abatiendo el tiránico, substituyendo el liberal, e igualmente echando fuera de nuestro suelo al enemigo español, que tanto se ha declarado contra (nuestra Patria / esta nación)."

El Congreso de Anáhuac fue, sin duda, uno de los pocos que emitieron declaraciones con un neto tinte social e igualitario, tendiente a avanzar hacia la igualdad:

" $12^{\circ}$ Que como la buena Ley es superior a todo hombre, las que dicte nuestro Congreso deben ser tales, que obliguen a constancia y patriotismo, moderen la opulencia y la indigencia; y de tal suerte se aumente el jornal del pobre, que mejore sus costumbres, alejando la ignorancia, la rapiña y el hurto." 41

Mientras que en la declaración de independencia del mismo Congreso, se lee:

"El Congreso de Anáhuac, legítimamente instalado en la ciudad de Chilpancingo, ... ha recobrado el ejercicio de su soberanía, usurpado; que, en tal concepto, queda rota para siempre jamás y disuelta la dependencia del trono español; ... declara por reo de alta traición a todo el que se oponga directa o indirectamente a su independencia, ya sea protegiendo a los europeos opresores, de obra, palabra o por escrito, ya negándose a contribuir con los gastos, subsidios y pensiones para continuar la guerra hasta que su independencia sea reconocida por las naciones extranjeras...". ${ }^{42}$

41. José María Morelos, Los sentimientos de la nación, 1813, pág. 2.

42. Acta de independencia del Congreso de Anáhuac, 6 de noviembre de 1813. 
Es necesario tener en cuenta que esto se hizo en los todavía tempranos años de 1812-1813, cuando ya se vislumbraba en el horizonte de la metrópolis la retirada de los franceses del territorio español y la vuelta al trono de Fernando VII, ocurrida en diciembre de 1813, y cuando podía preverse la reacción española.

En contraste con los demás movimientos iberoamericanos, incluido el del 5 de noviembre de 1811 en San Salvador, el de Anáhuac busca en las raíces indígenas precolombinas:
"¡Día grande, día fausto, venturoso día en que el sol alumbra con la luz más pura, aún a los más apáticos e indiferentes! ¡Genios de Moctezuma, Cacama, Quauhtemoctzin, Xícoténcatl y Caltzontzin, celebrad en torno de esta augusta asamblea y como celebráis el mitote en que fuisteis acometidos por la pérfida espada de Alvarado, el fausto momento en que vuestros ilustres hijos se han congregado para vengar vuestros ultrajes y desafueros y librarse de las garras de la tiranía y el fanatismo que los iba a sorber para siempre Al 12 de Agosto de 1521 sucedió el 14 de Septiembre de 1813; en aquél se apretaron las cadenas de nuestra servidumbre en México Tenochtitlan; en éste se rompen para siempre en el venturoso pueblo de Chilpancingo." 43

De hecho, la Constitución de Apatzingan que se declaró poco después, en 1814, dice que

"La ley es la expresión de la voluntad general en orden a la felicidad común. La felicidad del pueblo y de cada uno de los ciudadanos consiste en el goce de la igualdad, seguridad, propiedad y libertad, pues la íntegra conservación de estos derechos es el único fin de las asociaciones políticas. Son obligaciones de los ciudadanos una entera sumisión a las leyes, un obedecimiento absoluto a las autoridades constituidas, una pronta disposición para contribuir a los gastos públicos y un sacrificio demanden".

Y el art. 15 de la Constitución

“15. Que la esclavitud se proscriba para siempre y lo mismo la distinción de castas, quedando todos iguales, y sólo distinguirá a un americano del otro el vicio y la virtud." 44

Ningún otro movimiento de esos tiempos y lugares se animará a tanto. Es necesario tener en cuenta que el Congreso de Anáhuac no fue convocado por ningún cabildo. Por lo tanto, es poco probable que aquí encontraran la 
manifestación de sus esperanzas y ambiciones los criollos de las ciudades mexicanas. El Congreso se instala en una ciudad periférica,

"El Congreso de Anáhuac, legítimamente instalado en la ciudad de Chilpancingo" 45 y la declaración de independencia no cita en ningún momento las palabras 'pueblo' o 'patria'.

En 1816, las Provincias Unidas del Río de la Plata, Virreinato desde 1776, declaran su independencia en un Congreso reunido en la norteña ciudad de Tucumán, conformado por representantes de la mayoría de las regiones o provincias que lo componían. El temor de algunas provincias con respecto a la centralista Buenos Aires, que había demostrado su centralismo en ocasión de la revuelta de mayo de 1810, había llevado el congreso lejos de la capital. El texto de la declaración arroja también algunos datos interesantes.

Primeramente, se refiere a que

"Terminada la sesión ordinaria el Congreso de la Provincias Unidas continuó sus anteriores discusiones sobre el grande, augusto, y sagrado objeto de la independencia de los Pueblos que lo forman".

La alusión es clara y está referida a ‘los Pueblos que lo forman’ representados en el Congreso. Y los representantes ('diputados') declaran la independencia atendiendo a la propia suerte y de 'los Pueblos representados':

“...los Representantes, sin embargo consagraron a tan arduo toda la profundidad de sus talentos, la rectitud de sus intenciones e interés que demanda la sanción de la suerte suya, la de los Pueblos representados y la de toda la posteridad."

No deja lugar a dudas el carácter en el cual los firmantes del acta declaran la independencia:

"Nos los Representantes de las Provincias Unidas en Sud América, reunidos en Congreso General, invocando al Eterno que preside al universo, protestando al Cielo, a las naciones y hombres todos del globo, la justicia que regla nuestros votos: Declaramos solemnemente a la faz de la tierra que, es voluntad unánime e indudable de estas Provincias romper los violentos vínculos que las ligaban a los Reyes de España..."46

Como se ve, los diputados declaran la independencia en calidad de 'representantes de las Provincias' que los han elegido. Es necesario, en este punto, indagar acerca de la forma como han sido elegidos los representantes de cada provincia para decidir acerca de su representatividad. Sin duda, hay

45. Acta de independencia del Congreso de Anáhuac, 1813.

46. Acta de la declaración de la independencia Argentina, 1816. 
situaciones distintas, pero en general, estas elecciones se hicieron en torno a los cabildos de las capitales de cada provincia, donde los criollos, locales hicieron pesar sus ambiciones, en muchos casos, para tomar distancias con respecto a los de los criollos de la capital.

En los 'Procesos por infidencia contra los próceres salvadoreños de la independencia de Centroamérica desde 1811 hasta $1818^{\prime}{ }^{\prime 4}$, no encontraremos alusiones a la igualdad ni a la representatividad por parte de quienes lideraron las revueltas de 1811. Nos adentraremos en ello más abajo.

En el también aristocrático Alto Perú, en el que la presencia de dos universidades otorgaba un tinte intelectual y progresista a la clase de los criollos, la independencia se declara igualmente desde un congreso, reunido éste en 1825. La fecha es tardía, comparada con otras independencias. Sin embargo, los movimientos de revuelta, que comenzaron aquí ya desde fines del siglo XVIII, y los movimientos de principios del siglo XIX, los primeros del siglo, prepararon el terreno para la independencia. Al igual que en casos anteriores que mencionamos, tampoco en este caso el congreso que declara la independencia es convocado por un cabildo, sino por diputados que representan a las distintas regiones:

“La representación soberana de las provincias del Alto-Perú...",

" a nombre y absoluto poder de sus dignos representados" 48

En este caso, los diputados declaran la independencia como representantes de las regiones que representan. Como decíamos arriba, sería necesario aclarar la forma de elección de los representantes para determinar el grado de representatividad.

\section{El uso del vocablo ‘pueblo' en la revuelta de San Salvador de 1811}

La 'relación histórica' que traen los Procesos por infidencia presentan la narración de los succesos del 5 de noviembre de 1811 en San Salvador desde el punto de vista de los criollos. De hecho, es muy probable que haya sido escrita por uno de ellos, Juan Manuel Rodriguez, secretario del gobierno que asumió provisoriamente el poder político en San Salvador.

Esa 'relación' trae numerosas citas del vocablo y de otros a los que podría asimilarse, como 'vecindario', 'sociedad', 'todos', 'público', 'bulgo' (sic).

Detengámonos brevemente en algunos párrafos de esta 'relación'.

El documento cita que una

47. García, Miguel Á., Procesos por infidencia contra los próceres salvadoreños de la independencia de Centroamérica desde 1811 hasta 1818, Tomo I, Imprenta Nacional, San Salvador, 1940.

48. Acta de la independencia del Alto Perú, hoy Bolivia. 
“... parte considerable de la gran sociedad de este Rno. de Guatemala se ha visto conmovida pr. unos incidentes, al parecer, inconexos con la felicidad qe. todos desean, y nadie atina apromover pr. medios seguros." 49 ,

haciendo referencia a las manifestaciones populares del movimiento del 4 y 5 de noviembre. Aquí, una 'parte considerable del Reyno de Guatemala', define a las personas que habitan en San Salvador y han visto turbada su paz citadina por los sucesos del movimiento, y que probablemente han tomado parte en él. Se puede encontrar también aquí una justificación de los desórdenes. Los 'incidentes inconexos con la felicidad', sin duda, se refieren al rumor de amenazas contra la integridad de Cura Vicario de la ciudad, al llamamiento a la capital al sacerdote Manuel Aguilar -ambos criollos, tanto Delgado como Aguilary a la decisión del Alcalde de la ciudad de armar a los españoles europeos ante las posibles consecuencias del movimiento.

El documento sigue de esta forma:

"Si, repito, incidentes inconexos conmovieron este Pubco. Cabesas de la Provincia exitaron su odio y casicasillegaron aterminos de enfurecerle."

Aquí, 'Cabesas de la Provincia' está referido al Intendente de San Salvador, Antonio Guitiérrez y Ulloa, español peninsular y, por lo tanto, merecedeor de los recelos de los criollos. Si el Intendente español había armado a los españoles peninsulares, éste constituía un buen motivo para la efervescencia popular, que probablemente fomentaron los criollos para adueñarse posteriormente del movimiento.

El 'pueblo' a que hace referencia es, probablemente, la población de los suburbios de San Salvador alertada y seguramente, animada, por los alcaldes de los barrios, decíamos arriba. Aquí quedan fuera de este término los habitantes de los pueblos, las comunidades indígenas, incluso los habitantes de los suburbios que no estaban influidos por los dirigentes. El pueblo que sí se manifestó ese 5 de noviembre, según el documento que estamos presentando, manifestó sus reclamos:

“La reunion de este Publico. en el instante qe. supo tales procedimientos manifesto su noblesa, y como esta és inceparable, del sentimiento, se empeso a incinuar yá con voces de ternura, ya con de indignacion..."

La cita quiere dar a entender, probablemente, que el pueblo tenía reclamos que exteriorizar y lo hizo durante ese movimiento. Hemos presentado arriba algunos de estos reclamos.

49. García, M. A., Procesos por infidencia..., pág. 60. 
Decíamos también del desprecio con que con frecuencia los criollos se referían a 'las castas': mestizos, mulatos, negros, indios. El documento refleja este desprecio:

"Parece qe. al bulgo no le son Consedidas las luces suficientes para acertar en materias politicas, y es indispensable Creer qe. una mano oculta de absoluto poder, regia sus operaciones."

El término 'bulgo', por 'pueblo', está cargado de aristocrático desprecio. La cita justifica el hecho que los criollos tomaran la dirección del movimiento porque

"¿Quienes dirian al Pueblo qe. se formase en masa por si, sin Cabesa de persona distinguida que aconseje sus Operaciones? Un Cuerpo Acefalo es imposible qe. tenga aciertos. ¿Pues un Pueblo aque grado de desaciertos no llegaria?"

El mismo 'pueblo' que sirve de presión para desatar un movimiento que cuestiona la autoridad española en la colonia, que reclama por insatisfacciones atribuibles a esas autoridades y que a la postre dejará el movimiento en manos de 'las personas condecoradas', no tiene las luces suficientes para llevar adelante el movimiento que ha desatado, necesita que alguien le forme en masa y una cabeza que aconseje sus acciones, es imposible que tenga aciertos y puede llegar a cualquier grado de desaciertos...!

Sin embargo,

"Sola esta consideracion presenta el testimonio mas autentico de qe. el Pueblo procedia por una inspiracion sabia y superior",

lo que justificaba plenamente el movimiento que, dirigido por los criollos, llevaría los reclamos con la mesura necesaria:

"Pero reintegrados un tanto los espiritus de los Españoles Americanos, toman la vos para representar al Pueblo. qe. el movimiento multuario prometia grandes desastres..." 50

Para el documento en cuestión, se trata de un pueblo que sigue fielmente las indicaciones de los criollos y se deja guiar por ellos en sus reclamos:

"Cresian estas y la voceria hiso Ocurrir a las personas condecoradas. En efecto acreditó el Pueblo, que aquellos eran sentimientos verdaderamente del amor qe. profesa a sus Patricios; se contubo con sus suplicas, y Observó la tranquilidad qe. en aquel momento se le impuso."

50. García, M. A., Procesos por infidencia..., pág. 60. 
Los reclamos, según el texto del documento, habrían hecho acudir a los criollos -'personas condecoradas', 'patricios' -, que verificaron la validez del movimiento y le impusieron tranquilidad y mesura a los reclamos.

Luego, la palabra 'pueblo' pasa a significar solamente a los habitantes de la ciudad:

“...solo el desorden reinava, la confucion se esculpia en los habitantes de Sn. Salvador...".

Este desorden aumenta con la aparición de los españoles peninsulares y las autoridades a las cuales se dirigen los reclamos, precisamente, quienes deberían atenderlos y que sin embargo amenazan con reprimirlos:

"Concurrieron tambien el Sr. Yntendente y todos los Europeos ¿Pero aque? A exaltarse en Odio pubco. y el Pueblo ya no hace peticiones, sino qe. Clama contra ellos; de forma que repartido en varios trosos. a sestan las casas de éstos. y los que la noche antes le contubieron, toman empeño particular para reprimirle".

Cuando la destitución de las autoridades españolas es un hecho, es necesario nombrar nuevas autoridades. El derecho de hacerlo recae en el 'pueblo' protagonista de la asonada. Para ello,

"Se convocaron los Alcaldes, Prales y Padres de familia de sus respectivos Barrios. y se constituyeron a la casa de su representante en donde después de sancionar sus pensamientos: Acordaron, que el mando guvernativo, y politico...":

ahora, el 'pueblo' pasa a estar constituido por los Alcaldes, Principales y Padres de familia, quienes debían nombrar a las nuevas autoridades. De esta decisión quedaban excluidos, precisamente, quienes habían iniciado el movimiento con el tumulto del 4 y 5 de noviembre y provocado los primeros tumultos que despertaron la reacción de las autoridades coloniaes..

Una situación similar plantea el mismo documento cuando sostiene que quien se vio obligado a deponer a las autoridades españolas había sido el 'vecindario'.

"La serie de acontecimientos que con una rapides increible, ha puesto en movimiento, y alarmado así a todos los Pueblos de América, interesaron demaciado a esta Provincia, para mirar con indiferencia males y desgracias que algun dia ibamos a experimentar. Estas consideraciones han obligado al vecindario de esta capital a deponer el dia de hoy al Sr. Yntendente corregidor..."51 
En los tiempos de la colonia, se entendía por 'vecinos' a quienes tenían propiedad en el ámbito de la ciudad y cuyos intereses estaban representados en el cabildo: los españoles peninsulares y los criollos. En el caso de la revuelta de San Salvador de 1811 que venimos tratando aquí, es evidente que los primeros quedaban fuera de la posibilidad de participar en el nombramiento de las nuevas autoridades, pues contra ellos se había dirigido el movimiento. Por lo tanto, aquéllas debían ser nombradas por los españoles americanos. Y éstos nombraron a otros españoles americanos con los cuales tenían intereses comunes.

La 'relación histórica' de los sucesos de 1811, en su constante referencia al 'pueblo', guarda estrecha relación con al Acta del Cabildo de Buenos Aires del 25 de mayo de 1810, expresándose con términos similares. Veamos algunos fragmentos de ella, que reproducimos en el Anexo 4:

“...una representación que han hecho a este Excmo. Cabildo un considerable número de vecinos, los Comandantes y varios Oficiales de los Cuerpos voluntarios de esta Capital, por si y a nombre del Pueblo, en que indicando haber llegado a entender que la voluntad de éste... abiendo reasumido la autoridad y facultades que confió ... y quiere que este Excmo. Cabildo proceda a hacer nueva elección de los Vocales que hayan de constituir la Junta de Gobierno, y han de ser los señores ... cuya elección se deberá manifestar al Pueblo por medio de otro Bando público ... los referidos S.S. presten el juramento, sean reconocidos por depositarios de la Autoridad Superior del Vireynato por todas las corporaciones de esta Capital y su vecindario...". ${ }^{52}$

Como se ve, las similitudes son muy cercanas y los conceptos similares: el pueblo reasume la facultad de nombrar a las autoridades y declara caducas las hasta entonces vigentes, que representaban al rey. Sin embargo, aquí no se cuestiona la soberanía real, sino la mala actuación de las autoridades: 'muera el mal gobierno'.

Los 'representantes del pueblo' (criollos, también aquí!), indican al cabildo que debe nombrar nuevas autoridades y cuáles deben ser éstas. El cabildo debe manifestar ante el pueblo que ha designado por nuevas autoridades a las pesonas que se la ha indicado, las que deben prestar juramento ante 'las corporaciones de la ciudad capital y su vecindario'. El concepto de 'pueblo' se reduce ahora al de 'las corporaciones de la capital y su vecindario'; sus 'representantes' son los criollos, lo mismo que serán criollos casi todos los integrantes de la Junta de Gobierno.

En este aspecto, los países que nacieron de los procesos de independencia de las colonias españolas no dejaron de poner en evidencia en los documentos que emanaban de las revueltas, las múltiples influencias que sufrieron: 
la de las ideas de la ilustración y la revolución francesa, la de las colonias inglesas en América del Norte y la de la ilustración española, como decíamos arriba. Esta influencia se verifica también en el alcance del término 'pueblo'. Particularmente, los criollos que lideraron las revueltas admiraron las ideas y los resultados alcanzados por las antiguas colonias inglesas. Veamos algunos documentos en los que queda en evidencia esta influencia en el alcance del término 'pueblo'.

\section{Bibliografía}

Andrés-Gallego, José, Quince revoluciones y algunas cosas más, ed. Mapfre, en versión electrónica, Madrid, 1992.

García, M. A, De peruanos e indios: La figura del indígena en la intelectualidad y políticas criollas (Perú: siglos XVIII-XIX), ed. Universidad Internacional de Andalucía, Huelva, 2007.

Gazmuri R., Cristián, Ideas políticas francesas en la gestación de la independencia de Chile, en Comisión Organizadora de las Conmemoraciones de 2010, Las independencias iberoamericanas, Edición del Instituto Nacional de Estudios Històricos de las Revoluciones de México, México, 2010

Herrera, Sajid Alfredo, 1811. Relectura de los levantamientos y protestas en la Provincia de San Salvador, en Las independencias iberoamericanas, Comisión Organizadora de las Conmemoraciones de 2010, Edición del Instituto Nacional de Estudios Históricos de las Revoluciones de México, México, 2010.

Martínez Peláez, S., La patria del criollo. Ensayo de interpretación de la realidad colonial guatemalteca, México: Ediciones en Marcha, 1994, e Herrera, S., en revista Contrapunto, en versión electrónica.

Marroquín, A. Dagoberto, Apreciación sociológica de la Independencia salvadoreña, Dirección de Publicaciones e Impresos, San Salvador, 2000.

Peccorini Letona, Francisco, La Voluntad del Pueblo en la Emancipación de El Salvador, Dirección de Publicaciones e Impresos, San Salvador, 1972 